\title{
Application of the Meerwein reaction of 1,4-benzoquinone to a metal-free synthesis of benzofuropyridine analogues
}

\author{
Rashmi Singh ${ }^{1,2}$, Tomas Horsten ${ }^{2}$, Rashmi Prakash ${ }^{2}$, Swapan Dey ${ }^{* 1}$ and Wim Dehaen ${ }^{* 2}$
}

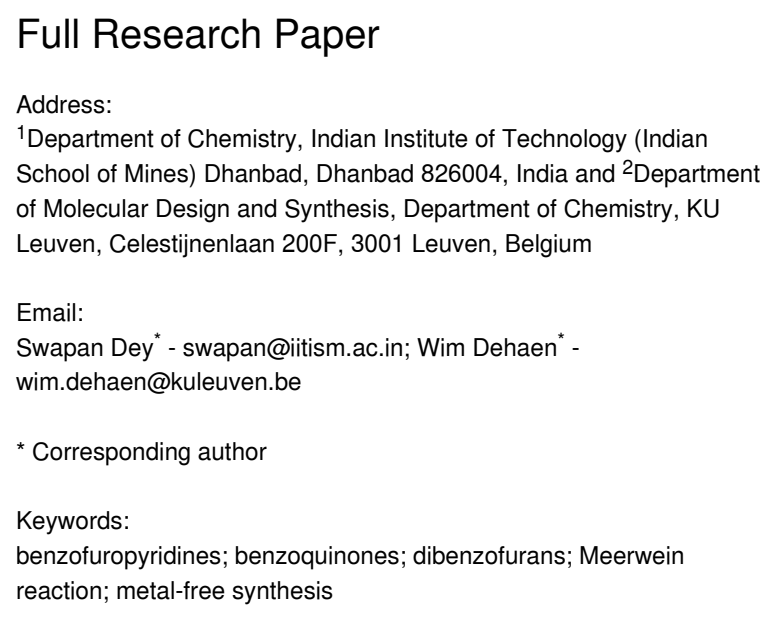

reaction; metal-free synthesis

Beilstein J. Org. Chem. 2021, 17, 977-982. https://doi.org/10.3762/bjoc. 17.79

Received: 16 February 2021

Accepted: 20 April 2021

Published: 30 April 2021

Associate Editor: T. J. J. Müller

(C) 2021 Singh et al.; licensee Beilstein-Institut.

License and terms: see end of document.

\begin{abstract}
Several new heterocyclic systems based on a hydroxybenzofuro[2,3- $b$ ]pyridine building block were prepared. This benzofuropyridine is easily available from the Meerwein reaction of benzoquinone and a heterocyclic diazonium salt, followed by reduction and cyclization. Electrophilic substitution and further condensations give polycyclic systems, including oxazolo- and chromeno-fused analogues.
\end{abstract}

\section{Introduction}

Dibenzofurans are important oxygen-containing heterocycles present in multiple natural products [1,2] and have broad applications in areas ranging from medicinal chemistry [1-10] to materials science [11]. Figure 1 presents a few examples of dibenzofuran-containing molecules. Benzofurocoumarin analogues of $\mathbf{1}$ have antiproliferative effects on human cancer cell lines [12,13]. Fluoroquinophenoxazines 2 have been used as telomerase inhibitors in anticancer research [14]. Furthermore, benzofuroisoindoles 3 were part of a kinase inhibitor study [15]. Photobiologically active psoralene (linear furocoumarin) dibenzofurans $\mathbf{1}$ and angular furanocoumarin dibenzofurans 4 were also explored for the treatment of various skin diseases [16]. Furthermore, 2-substituted benzofurobenzofurans 5 with antitubercular activity have been reported [17]. Prado et al. reported the antimycobacterial activity of furo[3,2-f]chromene analogue 6 [18].

The aza analogues of dibenzofuran have been less explored, although they may have significant bioactivity. Introducing nitrogen to the dibenzofuran system is expected to increase the water solubility and potential bioavailability due to enhanced hydrogen bonding. Figure 2 presents a few examples of 


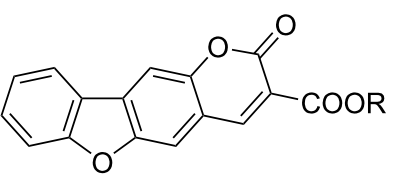

1

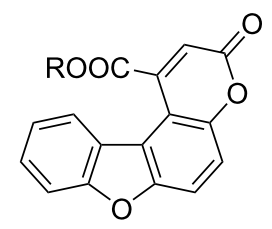

4<smiles>[R]OC(=O)c1cn2c3c(c(N4CC[C@@H](N)C4)c(F)cc3c1=O)Oc1cc3c(cc1-2)oc1ccccc13</smiles>

2

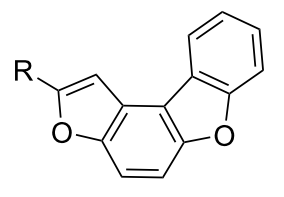

5<smiles>O=C1NC(=O)c2c1c([123I])cc1oc3ccc(O)cc3c21</smiles>

3

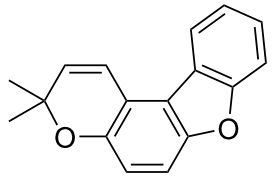

6

Figure 1: Biologically relevant 2-oxydibenzofuran-containing structures 1-6.

azadibenzofuran molecules. One example of a biologically active benzofuropyridine is revamilast (7), which has been used in Phase II clinical trials, studying the treatment of asthma and rheumatoid arthritis [19]. Other examples are the hydroxybenzofuro[2,3- $b$ ]pyridines 8 with efflux pump inhibitory activity useful in chemotherapy $[20,21]$. These compounds are presumably multitargeting drugs because of the diverse applications as insulin-like growth factor 1 receptor (IGF-1R) inhibitors [22], selective GSK-3 $\beta$ inhibitors important in Alzheimer's disease [23,24], and cyclin-dependent kinase (CDK) inhibitors [25-27]. Lastly, the aza analogue 9 of previously reported furo[3,2$f$ chromene $\mathbf{6}$ was examined for antimycobacterial activity [28].<smiles>O=C(Nc1c(Cl)c[n+]([O-])cc1Cl)c1ccc(OC(F)F)c2oc3ccncc3c12</smiles>

7
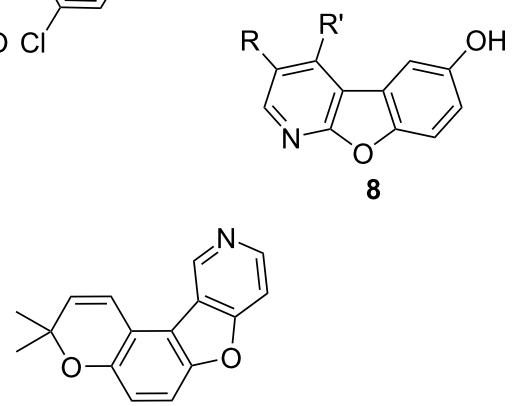

9

Figure 2: Representative bioactive structures containing benzofurofused pyridine analogues 7-9.

This evidence encouraged us to investigate new methodologies for the synthesis of aza analogues of dibenzofuran from com- mercially available aminochloropyridines. Furthermore, a diverse set of polycyclic derivatives was designed. The procedures towards such polycyclic building blocks include $\mathrm{C}-\mathrm{H}$ arylation strategies. In the classical Meerwein reaction, aryldiazonium salts are used as the reagents to couple aryl groups to electron-poor alkenes, and this process is assumed to proceed via a free-radical mechanism [29]. Similar reaction intermediates can be prepared using precursors such as organoboron reagents [30]. However, due to the accessibility, aryldiazonium salts are the reagents of choice. They can be prepared starting from the commercially available corresponding anilines. The present work focuses on a metal-free approach for the synthesis of benzofuropyridine analogues.

\section{Results and Discussion}

The synthesis of target compound $\mathbf{1 3}$ involved three steps (Scheme 1). C-H Arylation, as needed in the first step, is usually carried out using transition metal catalysis [31]. Furthermore, various metal-based approaches for arylation of quinone involving electrochemical [32], oxidative [33], and photochemical methods [34-36] are also available in the literature [37]. Langer and co-workers reported the synthesis of benzofuropyridines based on a domino reaction of 3-chlorochromones with aminoheterocycles [38]. Alternatively, the classical Meerwein reaction can be applied starting from 3-amino-2-chloropyridine (10), which was transformed into the diazonium salt and coupled in situ with 1,4-benzoquinone, forming arylated quinone 11 without an additional reducing agent [39]. The quinone was reduced to hydroquinone 12 with $N, N$-diethylhydroxylamine ( $N, N$-DEHA) and cyclized via intramolecular nucleophilic aromatic substitution to isolate 6-hydroxybenzofuro[2,3-b]pyridine (13) with $82 \%$ yield. Conveniently, the syn- 

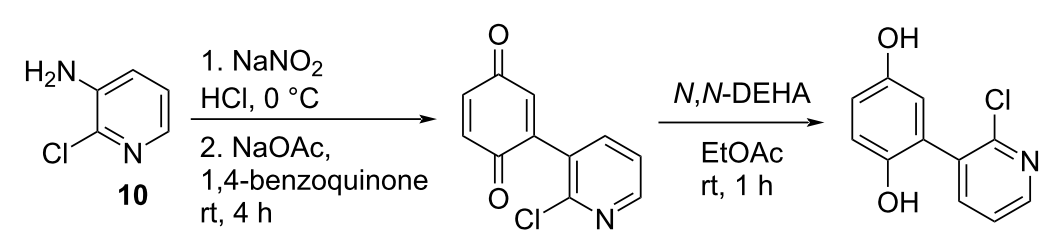

$11(57 \%)$

$12(90 \%)$

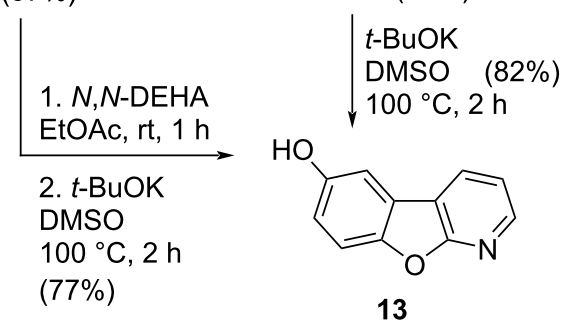

Scheme 1: Strategy for metal-free access to benzofuropyridine 13

thesis of $\mathbf{1 3}$ was achieved in a one-pot reaction from $\mathbf{1 1}$ with no significant differences in the yield. To the best of our knowledge, this is the first procedure toward compound 13, without additional substituents on the pyridine ring. Furthermore, this method is complementary to the most common routes towards the biologically active 1-aza-9-oxafluorenes [20-26].

To expand the library of derivatives containing core structure 13, electrophilic aromatic substitution of this compound was explored (Scheme 2). Nitration of $\mathbf{1 3}$ using $\mathbf{7 0 \%}$ nitric acid in glacial acetic acid gave the corresponding regioisomers 14 and 15 in $53 \%$ and $41 \%$ isolated yield, respectively. The ${ }^{1} \mathrm{H}$ NMR spectrum of $\mathbf{1 5}$ showed two apparent singlets separately at $\delta_{\mathrm{H}} 7.86$ and $\delta_{\mathrm{H}} 8.35$, which confirmed that the hydrogen atoms of the phenol ring had a para-relationship. The ${ }^{1} \mathrm{H}$ NMR spectrum of compound $\mathbf{1 4}$ was similar to that of compound $\mathbf{1 5}$ concerning the pyridine part. However, two separate doublet signals appeared at $\delta_{\mathrm{H}} 7.98(\mathrm{~d}, J=9.1 \mathrm{~Hz}, 1 \mathrm{H})$ and $\delta_{\mathrm{H}} 7.35(\mathrm{~d}$, $J=9.0 \mathrm{~Hz}, 1 \mathrm{H})$ indicating an ortho-relationship between the hydrogen atoms positioned on the phenolic ring.
Several methods of formylation of $\mathbf{1 3}$ were attempted, e.g., Vilsmeier formylation, where only the unstable formate ester was formed. Following the Duff formylation procedure, only traces of aldehyde $\mathbf{1 6}$ were detected. Rieche formylation with either $\mathrm{SnCl}_{4}$ or $\mathrm{TiCl}_{4}$ resulted in a low conversion of the starting material and only traces of $\mathbf{1 6}$ due to the limited solubility of $\mathbf{1 3}$ in DCM, DCE, or chloroform. Furthermore, 16 was isolated after a Reimer-Tiemann formylation; however, only in $13 \%$ yield. Finally, Casnati-Skattebøl formylation of $\mathbf{1 3}$ using $\mathrm{MgCl}_{2}, \mathrm{iPr}_{2} \mathrm{EtN}$, and paraformaldehyde, i.e., $\left(\mathrm{CH}_{2} \mathrm{O}\right)_{n}$, has been successful in regioselectively affording aldehyde 16 in a reasonable yield of $39 \%$. The regioselectivity of compound $\mathbf{1 6}$ was confirmed by ${ }^{1} \mathrm{H}$ NMR spectroscopy, which indicated the presence of two doublets at $\delta_{\mathrm{H}} 7.88(\mathrm{~d}, J=9 \mathrm{~Hz}, 1 \mathrm{H})$ and $\delta_{\mathrm{H}} 7.19$ (d, $J=8.9 \mathrm{~Hz}, 1 \mathrm{H}$ ), corresponding to the two adjacent hydrogen atoms of the phenolic ring. One singlet was observed at $\delta_{\mathrm{H}} 10.58$, evidencing the aldehyde proton. This access to previously unknown compounds 14-16 opens many synthetic possibilities for the preparation of novel fused derivatives of 1-aza-9oxafluorene.

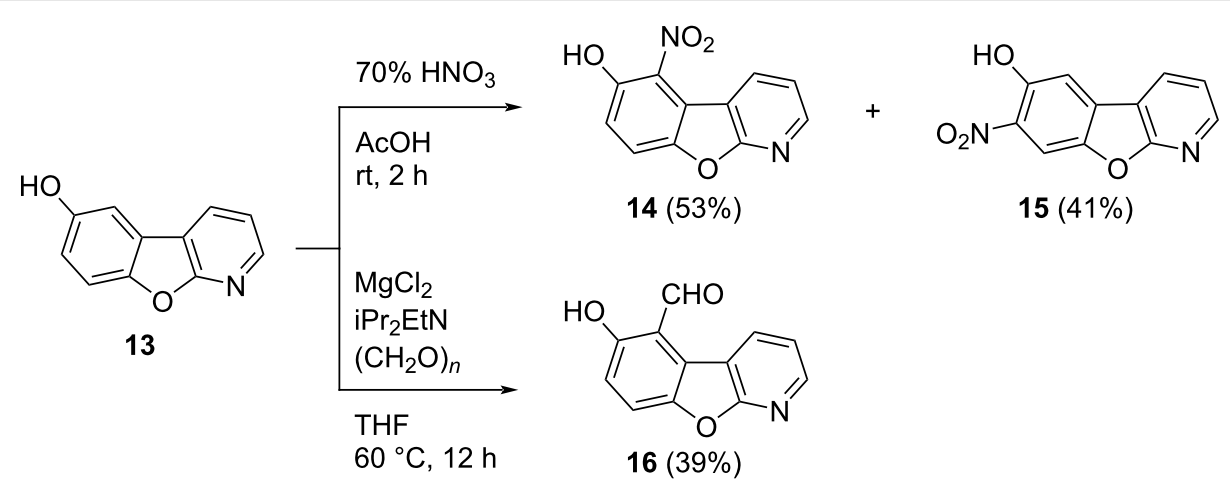

Scheme 2: Electrophilic aromatic substitution of 6-hydroxybenzofuro[2,3-b]pyridine (13). 
The nitro compounds $\mathbf{1 4}$ and $\mathbf{1 5}$ were reduced to the corresponding aniline derivatives using hydrogen and $\mathrm{Pd} / \mathrm{C}$ as a catalyst. The resulting aminophenols $\mathbf{1 7}$ and $\mathbf{1 8}$ were further converted to novel oxazole-fused derivatives 19 and $\mathbf{2 0}$, respectively, by condensation with benzaldehyde and subsequent 2,3dichloro-5.6-dicyano- $p$-benzoquinone (DDQ)-mediated oxidation (Scheme 3).

Aldehyde building block 16 was a versatile starting material for further cyclization reactions. Synthesis of nitrochromenobenzofuropyridine $\mathbf{2 1}$ was achieved after treatment of $\mathbf{1 6}$ with nitrostyrene in the presence of DABCO applying our previously reported ball milling procedure [40]. The synthesis of 22 was performed using the Perkin reaction [41]. The reaction of $\mathbf{1 6}$ with propionic anhydride and the corresponding sodium salt in the presence of a catalytic amount of piperidine afforded pyridopsoralen 22 in $46 \%$ yield. Analogously, pyridopsoralen 23 was prepared from 16 by Knoevenagel condensation with diethyl malonate and subsequent lactonization with $62 \%$ yield (Scheme 4) [13]. To the best of our understanding, the scaffolds 21-23 are novel and may have a potential medicinal interest.

\section{Conclusion}

In conclusion, we have successfully synthesized hydroxysubstituted pyridobenzofuran 13. Furthermore, nitration of $\mathbf{1 3}$ yielded two regioisomers, $\mathbf{1 4}$ and $\mathbf{1 5}$, which were further converted to oxazoles $\mathbf{1 9}$ and $\mathbf{2 0}$. Formylation of $\mathbf{1 3}$ was regioselective in forming 16, which is a valuable building block for various condensation reactions to yield a diverse set of products, such as polycyclic fused nitrochromenes $\mathbf{2 1}$ as well as pyridopsoralens $\mathbf{2 2}$ and 23. All these novel scaffolds are interesting structures with potential medicinal applications, and we plan to expand this chemistry and carry out a bioactivity study in due course.

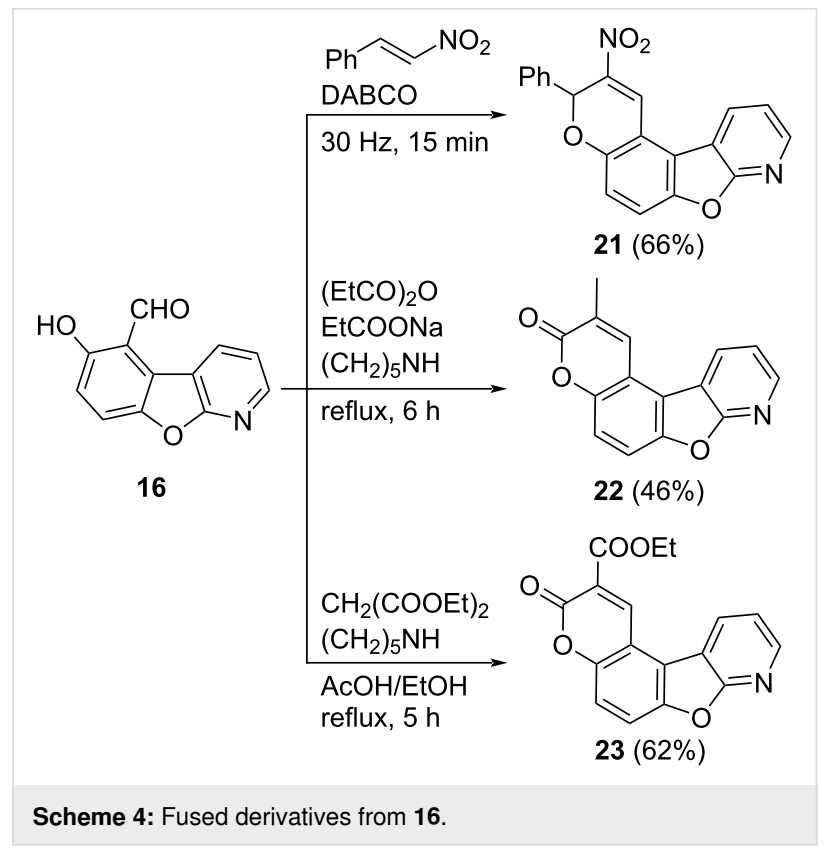

\section{Supporting Information}

\section{Supporting Information File 1}

Experimental part as well as ${ }^{1} \mathrm{H}$ and ${ }^{13} \mathrm{C}$ NMR data. [https://www.beilstein-journals.org/bjoc/content/ supplementary/1860-5397-17-79-S1.pdf]

\section{Funding}

We thank the KU Leuven for financial support. KU Leuven (Project C14/19/78). R. S. thanks IIT (ISM) Dhanbad for a graduate fellowship. Mass spectrometry was made possible by the support of the Hercules Foundation of the Flemish Government (grant 20100225-7).<smiles>O=[N+]([O-])c1c(O)ccc2oc3ncccc3c12</smiles>

14<smiles>O=[N+]([O-])c1cc2oc3ncccc3c2cc1O</smiles>

15

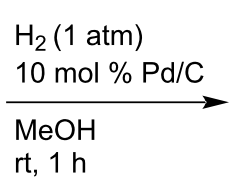

$\mathrm{H}_{2}$ (1 atm)

$10 \mathrm{~mol} \% \mathrm{Pd} / \mathrm{C}$

$\mathrm{MeOH}$

$\mathrm{rt}, 1 \mathrm{~h}$<smiles>Nc1c(O)ccc2oc3ncccc3c12</smiles>

17

$\begin{aligned} & \text { 1. } \mathrm{PhCHO} \\ & \mathrm{MeOH} \\ & 45^{\circ} \mathrm{C}, 12 \mathrm{~h} \\ & \stackrel{2}{2} \mathrm{DDQ} \\ & \mathrm{CH}_{2} \mathrm{Cl}_{2} \\ & \text { rt, } 0.5 \mathrm{~h}\end{aligned}$

1. $\mathrm{PhCHO}$

$\mathrm{MeOH}$ $45^{\circ} \mathrm{C}, 12 \mathrm{~h}$

2. $\mathrm{DDQ}$

$\mathrm{CH}_{2} \mathrm{Cl}_{2}$

$\mathrm{rt}, 0.5 \mathrm{~h}$
$\mathrm{Ph}$<smiles>Cc1nc2c(ccc3oc4ncccc4c32)o1</smiles>

$19(71 \%)$<smiles>c1ccc(-c2nc3cc4oc5ncccc5c4cc3o2)cc1</smiles>

$20(66 \%)$ 


\section{ORCID ${ }^{\circledR}$ iDs}

Rashmi Singh - https://orcid.org/0000-0003-1770-973X Tomas Horsten - https://orcid.org/0000-0003-4233-6031 Wim Dehaen - https://orcid.org/0000-0002-9597-0629

\section{References}

1. Shou, Q.; Banbury, L. K.; Renshaw, D. E.; Lambley, E. H.; Mon, H.; Macfarlane, G. A.; Griesser, H. J.; Heinrich, M. M.; Wohlmuth, H. J. Nat. Prod. 2012, 75, 1612-1617. doi:10.1021/np300433r

2. Setzer, W. N.; Rozmus, G. F.; Setzer, M. C.; Schmidt, J. M.; Vogler, B.; Reeb, S.; Jackes, B. R.; Irvine, A. K. J. Mol. Model. 2006, 12, 703-711. doi:10.1007/s00894-005-0047-1

3. De Lombaert, S.; Blanchard, L.; Stamford, L. B.; Tan, J.; Wallace, E. M.; Satoh, Y.; Fitt, J.; Hoyer, D.; Simonsbergen, D.; Moliterni, J.; Marcopoulos, N.; Savage, P.; Chou, M.; Trapani, A. J.; Jeng, A. Y. J. Med. Chem. 2000, 43, 488-504. doi:10.1021/jm990507o

4. Kaul, R.; Deechongkit, S.; Kelly, J. W. J. Am. Chem. Soc. 2002, 124, 11900-11907. doi:10.1021/ja020675x

5. Carney, J. R.; Krenisky, J. M.; Williamson, R. T.; Luo, J. J. Nat. Prod. 2002, 65, 203-205. doi:10.1021/np010374l

6. Petrassi, H. M.; Johnson, S. M.; Purkey, H. E.; Chiang, K. P.; Walkup, T.; Jiang, X.; Powers, E. T.; Kelly, J. W. J. Am. Chem. Soc. 2005, 127, 6662-6671. doi:10.1021/ja044351f

7. Momotake, A.; Lindegger, N.; Niggli, E.; Barsotti, R. J.; Ellis-Davies, G. C. R. Nat. Methods 2006, 3, 35-40. doi:10.1038/nmeth821

8. Fang, L.; Fang, X.; Gou, S.; Lupp, A.; Lenhardt, I.; Sun, Y.; Huang, Z.; Chen, Y.; Zhang, Y.; Fleck, C. Eur. J. Med. Chem. 2014, 76, 376-386. doi:10.1016/j.ejmech.2014.02.035

9. Lin, R.-D.; Chen, M.-C.; Liu, Y.-L.; Lin, Y.-T.; Lu, M.-K.; Hsu, F.-L.; Lee, M.-H. Int. J. Mol. Sci. 2015, 16, 28598-28613. doi:10.3390/ijms161226115

10. Love, B. E. Eur. J. Med. Chem. 2015, 97, 377-387. doi:10.1016/j.ejmech.2015.01.005

11. Ito, T.; Sasabe, H.; Nagai, Y.; Watanabe, Y.; Onuma, N.; Kido, J. Chem. - Eur. J. 2019, 25, 7308-7314. doi:10.1002/chem.201805907

12. Francisco, C. S.; Rodrigues, L. R.; Cerqueira, N. M. F. S. A.; Oliveira-Campos, A. M. F.; Rodrigues, L. M. Eur. J. Med. Chem. 2012, 47, 370-376. doi:10.1016/j.ejmech.2011.11.005

13. Oliveira, A. M. A. G.; Raposo, M. M. M.; Oliveira-Campos, A. M. F.; Griffiths, J.; Machado, A. E. H. Helv. Chim. Acta 2003, 86, 2900-2907. doi:10.1002/hlca.200390237

14. Duan, W.; Rangan, A.; Vankayalapati, H.; Kim, M. Y.; Zeng, Q.; Sun, D.; Han, H.; Fedoroff, O. Y.; Nishioka, D.; Rha, S. Y.; Izbicka, E.; Von Hoff, D. D.; Hurley, L. H. Mol. Cancer Ther. 2001, 1, 103-120.

15. Wichapong, K.; Lindner, M.; Pianwanit, S.; Kokpol, S.; Sippl, W. Eur. J. Med. Chem. 2009, 44, 1383-1395. doi:10.1016/j.ejmech.2008.09.027

16. Eduardo Paiva Sena Maia, J.; de Lucas, N. C.; Cesarin-Sobrinho, D.; da Hora Machado, A. E.; Netto-Ferreira, J. C. J. Photochem. Photobiol., A 2016, 326, 21-29. doi:10.1016/j.jphotochem.2016.04.013

17. Yempala, T.; Sridevi, J. P.; Yogeeswari, P.; Sriram, D.; Kantevari, S. Bioorg. Med. Chem. Lett. 2013, 23, 5393-5396. doi:10.1016/j.bmcl.2013.07.048

18. Prado, S.; Ledeit, H.; Michel, S.; Koch, M.; Darbord, J. C.; Cole, S. T.; Tillequin, F.; Brodin, P. Bioorg. Med. Chem. 2006, 14, 5423-5428. doi:10.1016/j.bmc.2006.03.033
19. Balasubramanian, G.; Narayanan, S.; Andiappan, L.; Sappanimuthu, T.; Thirunavukkarasu, S.; Sundaram, S.; Natarajan, S.; Sivaraman, N.; Rajagopal, S.; Nazumudeen, F. A. A.; Saxena, S.; Vishwakarma, S. L.; Narayanan, S.; Sharma, G. V. R.; Srinivasan, C. V.; Kilambi, N. Bioorg. Med. Chem. 2016, 24, 5702-5716. doi:10.1016/j.bmc.2016.09.011

20. Brachwitz, K.; Hilgeroth, A. Bioorg. Med. Chem. Lett. 2002, 12 , 411-413. doi:10.1016/s0960-894x(01)00769-7

21. Krug, M.; Voigt, B.; Baumert, C.; Lüpken, R.; Molnár, J.; Hilgeroth, A. Eur. J. Med. Chem. 2010, 45, 2683-2688. doi:10.1016/j.ejmech.2010.02.024

22. Krug, M.; Erlenkamp, G.; Sippl, W.; Schächtele, C.; Totzke, F.; Hilgeroth, A. Bioorg. Med. Chem. Lett. 2010, 20, 6915-6919. doi:10.1016/j.bmcl.2010.10.004

23. Voigt, B.; Krug, M.; Schächtele, C.; Totzke, F.; Hilgeroth, A. ChemMedChem 2008, 3, 120-126. doi:10.1002/cmdc.200700175

24. Tell, V.; Mahmoud, K. A.; Wichapong, K.; Schächtele, C.; Totzke, F.; Sippl, W.; Hilgeroth, A. Med. Chem. Commun. 2012, 3, 1413. doi:10.1039/c2md20201h

25. Brachwitz, K.; Voigt, B.; Meijer, L.; Lozach, O.; Schächtele, C.; Molnár, J.; Hilgeroth, A. J. Med. Chem. 2003, 46, 876-879. doi:10.1021/jm021090g

26. Voigt, B.; Meijer, L.; Lozach, O.; Schächtele, C.; Totzke, F.; Hilgeroth, A. Bioorg. Med. Chem. Lett. 2005, 15, 823-825. doi:10.1016/j.bmcl.2004.10.091

27. Tell, V.; Holzer, M.; Herrmann, L.; Mahmoud, K. A.; Schächtele, C.; Totzke, F.; Hilgeroth, A. Bioorg. Med. Chem. Lett. 2012, 22, 6914-6918. doi:10.1016/j.bmcl.2012.09.006

28. Prado, S.; Toum, V.; Saint-Joanis, B.; Michel, S.; Koch, M.; Cole, S.; Tillequin, F.; Janin, Y. Synthesis 2007, 1566-1570. doi:10.1055/s-2007-966019

29. Meerwein, H.; Büchner, E.; van Emster, K. J. Prakt. Chem. 1939, 152, 237-266. doi:10.1002/prac.19391520705

30. Fujiwara, Y.; Domingo, V.; Seiple, I. B.; Gianatassio, R.; Del Bel, M.; Baran, P. S. J. Am. Chem. Soc. 2011, 133, 3292-3295. doi:10.1021/ja111152z

31. Itahara, T. J. Org. Chem. 1985, 50, 5546-5550. doi:10.1021/jo00350a023

32. Waldvogel, S. R.; Lips, S.; Selt, M.; Riehl, B.; Kampf, C. J. Chem. Rev. 2018, 118, 6706-6765. doi:10.1021/acs.chemrev.8b00233

33. T.P, A. K.; Pandaram, S.; llangovan, A. Org. Chem. Front. 2019, 6, 3244-3251. doi:10.1039/c9qo00623k

34. Wang, L.; Shen, J.; Yang, S.; Liu, W.; Chen, Q.; He, M. Green Chem. 2018, 20, 1290-1296. doi:10.1039/c8gc00012c

35. Fürst, M. C. D.; Gans, E.; Böck, M. J.; Heinrich, M. R. Chem. - Eur. J. 2017, 23, 15312-15315. doi:10.1002/chem.201703954

36. Schroll, P.; Hari, D. P.; König, B. ChemistryOpen 2012, 1, 130-133. doi:10.1002/open.201200011

37. Wang, Y.; Zhu, S.; Zou, L.-H. Eur. J. Org. Chem. 2019, 2179-2201. doi:10.1002/ejoc.201900028

38. Miliutina, M.; Janke, J.; Hassan, S.; Zaib, S.; Iqbal, J.; Lecka, J.; Sévigny, J.; Villinger, A.; Friedrich, A.; Lochbrunner, S.; Langer, P. Org. Biomol. Chem. 2018, 16, 717-732. doi:10.1039/c7ob02729j

39. Carlson, B. W.; Miller, L. L. J. Am. Chem. Soc. 1985, 107, 479-485. doi:10.1021/ja00288a035

40. Vroemans, R.; Verhaegen, Y.; Dieu, M. T. T.; Dehaen, W. Beilstein J. Org. Chem. 2018, 14, 2689-2697. doi:10.3762/bjoc.14.246

41. Gia, O.; Uriarte, E.; Zagotto, G.; Baccichetti, F.; Antonello, C.; Marciani-Magno, S. J. Photochem. Photobiol., B 1992, 14, 95-104. doi:10.1016/1011-1344(92)85085-9 


\section{License and Terms}

This is an Open Access article under the terms of the Creative Commons Attribution License (https://creativecommons.org/licenses/by/4.0). Please note that the reuse, redistribution and reproduction in particular requires that the author(s) and source are credited and that individual graphics may be subject to special legal provisions.

The license is subject to the Beilstein Journal of Organic Chemistry terms and conditions:

(https://www.beilstein-journals.org/bjoc/terms)

The definitive version of this article is the electronic one which can be found at:

https://doi.org/10.3762/bjoc.17.79 